\title{
Development of hybrid composite radar wave absorbing structure for stealth applications
}

\author{
T ANNIL KUMAR ${ }^{1, *}$ (D), J INAYATHULLAH ${ }^{1}$, V A NAGARAJAN ${ }^{2}$ and S HARI KUMAR ${ }^{3}$ \\ ${ }^{1}$ Department of Aeronautical Engineering, Noorul Islam Centre for Higher Education, Kumaracoil 629 180, India \\ ${ }^{2}$ Department of Mechanical Engineering, University College of Engineering, Nagercoil 629 004, India \\ ${ }^{3}$ Department of Communication Engineering, Noorul Islam Centre for Higher Education, Kumaracoil 629 180, India
}

MS received 1 April 2015; accepted 15 September 2015

\begin{abstract}
The ideally invisible stealth radomes are usually sandwiched constructions composed of E-glass/epoxy composite, polyvinyl chloride foam and frequency selective surfaces (FSS). Nylon 6/6 and balsa wood are well known for their low dielectric properties. In this work the electromagnetic (EM) wave transmission characteristics of the existing stealth radomes were improved by employing nylon 6/6 fibre and balsa wood, along with E-glass/epoxy composite without compromising the mechanical properties. The free space measurement technique was performed to measure the EM wave transmission characteristics in the $\mathrm{X}$-band frequency range $(8.2-12.4 \mathrm{GHz})$ for a specific FSS. The flexural strength of the sandwiched constructions were investigated with three-point bending test.
\end{abstract}

Keywords. Stealth; radomes; sandwich; balsa wood; nylon 6/6.

\section{Introduction}

The ability of microwave radars to detect distant airborne vehicles led to the invention of stealth technology. Rao and Mahulikar [1] argue that 'Stealth technology is one of the military tactics and passive electronic countermeasures'. Mahulikar and Sonawane [2] argue that 'Stealth techniques applied to personnel, aircraft, ships, submarines, missiles and satellites act as a camouflage and makes them less visible (ideally invisible) to radar and other detection methods'.

Chin and Lee [3] argue that 'the performance of stealth technique can be improved by minimizing the radar cross section (RCS) of a weapon system as the distance detected by opposite radar is proportional to the fourth root of RCS'. Kim and Lee [4] argue that 'the RCS describes the extent to which an object reflects an incident EM wave and it is a measure of the strength of the radar signal backscattered from a target object for a given incident EM wave power'.

Kim and Chin [5] argue that 'three techniques are broadly suggested for RCS reduction namely shaping of the vehicle, radar wave absorbing materials (RAM) and radar wave absorbing structure (RAS)'. Seo and Chin [6] argue that 'Shaping of the vehicle conflicts with the aerodynamic design requirements while RAM applied as a thick layer to the vehicle increases the weight and also needs to be periodically repaired'. Chin and Lee [7] argue that the 'RAS embedded as a load bearing structure transmits the EM waves without disturbing the external profiles set by the vehicle designers'.

Kim et al [8] argue that 'Since the RCS of the weapon systems is increased by radar antenna, the stealth technology

*Author for correspondence (annilkumartngl@gmail.com) must be applied for it, to prevent the radar detection'. Choi et al [9] argue that 'the RAS protecting the radar antenna is also called as radome, as indicated in figure 1a and b'.

Kim et al [10] argue that 'the functional requirements (FRs) of a stealth radome are as follows'.

- $F R_{1}$ : has resonance in the $\mathrm{X}$ band frequency range (8.2$12.4 \mathrm{GHz})$.

- $F R_{2}$ : has more than $80 \%$ of transmission rate.

- $F R_{3}$ : has less than $1 \mathrm{GHz}$ of the bandwidth for $-1 \mathrm{~dB}$.

- $F R_{4}$ : has high flexural strength.

Kim et al [10] argue that 'the existing stealth radomes are sandwiched constructions of E-glass/epoxy composite, polyvinyl chloride (PVC) foam (as they have low dielectric values with greater flexural strength) and a frequency selective surface (FSS)'.

In this work nylon fibre/epoxy composite is used as a substitute for E-glass/epoxy composite and balsa wood instead of PVC foam as the two have low dielectric properties and the latter has greater mechanical strength.

\section{Specification of the materials used}

The plain weave E-glass fibre and epoxy resin is purchased from Leo Enterprises-India. The properties of the E-glass fibre are listed in table 1.

The density of the epoxy resin is $1.36 \times 10^{3} \mathrm{~kg} \mathrm{~m}^{-3}$. The nylon $6 / 6$ fibres, balsa wood $\left(\rho=110 \mathrm{~kg} \mathrm{~m}^{-3}\right)$, and PVC foam (HT110, $\rho=110 \mathrm{~kg} \mathrm{~m}^{-3}$ ) are purchased from AGS Marine Agency-India. The thickness of the nylon fibres is $0.128 \mathrm{~mm}$. 

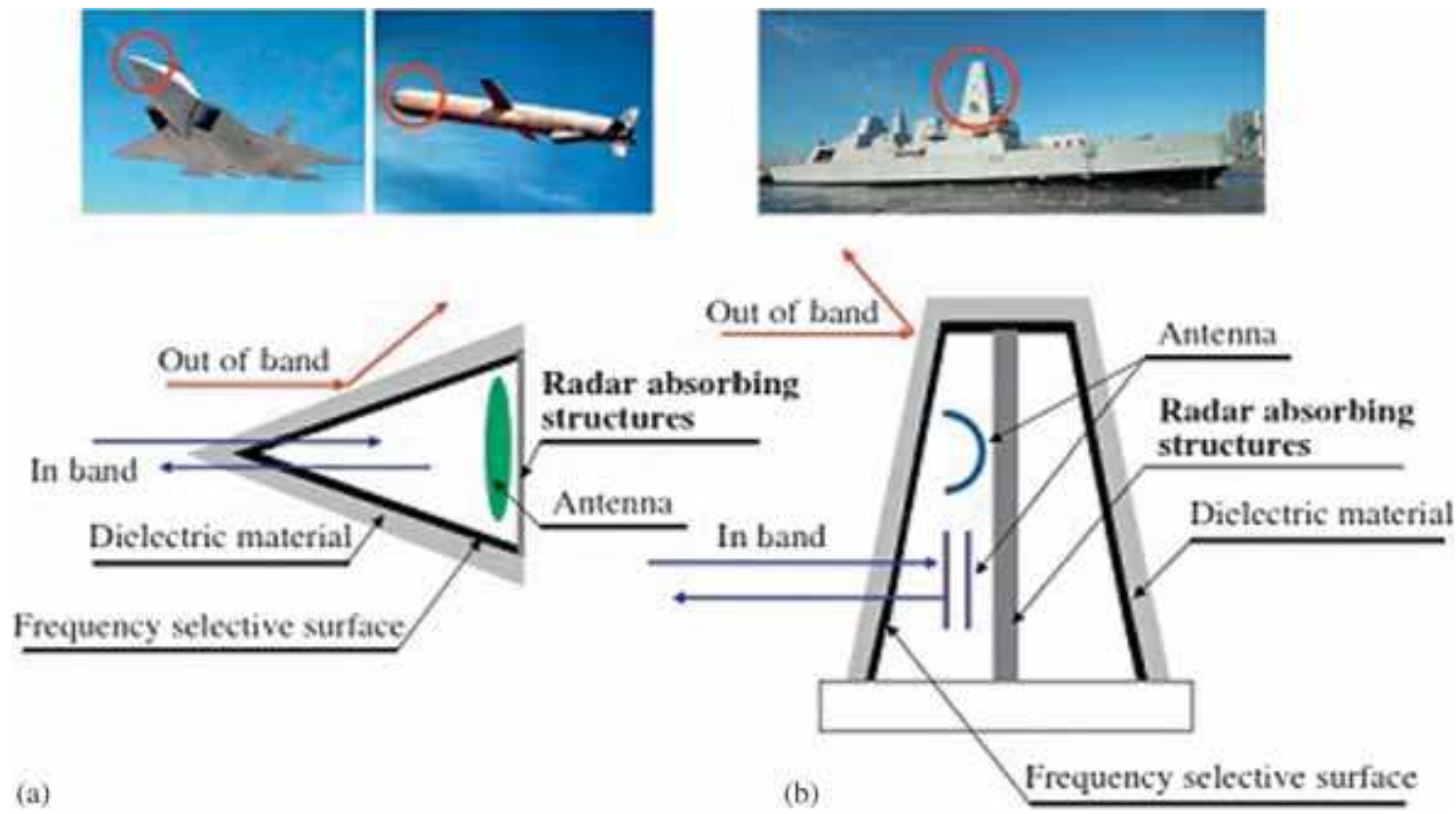

Figure 1. Schematic diagram of the stealth radomes: (a) aircraft and (b) warship.

Table 1. Properties of the E-glass fibre.

\begin{tabular}{lc}
\hline Properties & Value \\
\hline Thickness of the ply (mm) & 0.126 \\
Density the ply $\left(\mathrm{kg} \mathrm{m}^{-3}\right)$ & $2.6 \times 10^{3}$ \\
\hline
\end{tabular}

Choi et al [11] argue that 'A thin polyimide film of $4 \mu \mathrm{m}$ thickness coated over a $20 \mu \mathrm{m}$ thick copper foil constitutes the FSS'. The FSS with dipoles and its unit cell are shown in figure 2 .

Kim et al [10] argue that 'the size (a, b) and array periodicity $\left(\delta_{\mathrm{a}}, \delta_{\mathrm{b}}\right)$ of dipoles are $1,13,4$ and $17 \mathrm{~mm}$, respectively'.

\section{Dielectric properties of the materials}

The dielectric properties of the materials used are listed in table 2.

Choi et al [11] argue that 'Since the dielectric properties of balsa wood and PVC foam is closer to air, they act as a filler material, and their impact on electromagnetic wave transmission can be neglected'. The dielectric constant and loss tangent has the tendency to reduce, as the frequency of the EM waves are increased.

\section{Fabrication of the sandwich RAS}

Choi et al [11] argue that 'the existing stealth radome is a sandwich construction of glass/epoxy, PVC foam and FSS as shown in figure 3a'. The thickness of face material $\left(t_{\mathrm{f}}\right)$ is $1.008 \mathrm{~mm}$ and the core $\left(t_{\mathrm{c}}\right)$ is $10 \mathrm{~mm}$.

Kim et al [16] argue that 'the face materials of the radome E-glass/epoxy prepreg and nylon/epoxy prepreg are cured as stated in the cycle shown in figure 4 a by using autoclave vacuum bag degassing method'. Kim et al [16] argue that 'the epoxy adhesive (Araldite ${ }^{\circledR}$, India) is used to bond the FSS, E-glass/epoxy composite, PVC foam, nylon/epoxy composite and balsa wood, the bonding cycle of the epoxy adhesive is shown in figure $4 b$ '.

\section{Sandwich RAS configuration}

Six types of sandwich construction configurations are developed. The sandwich type, configuration, and its identification code are shown in table 3. The front face consists of E-glass/ epoxy composite, and the modifications are made in the core and back face without changing the dimensions. The specimens are machined to $250 \mathrm{~mm}$ (width) $\times 250 \mathrm{~mm}$ (length).

\section{Electromagnetic wave transmission measurement}

The electromagnetic wave transmission characteristics are measured by the free space measurement system as shown in figure 5 .

The test is conducted in the $\mathrm{X}$-band frequency range $(8.2-12.4 \mathrm{GHz})$. The antennas are separated by twice the focal distance $105 \mathrm{~mm}$ and the specimen is kept at the middle. 


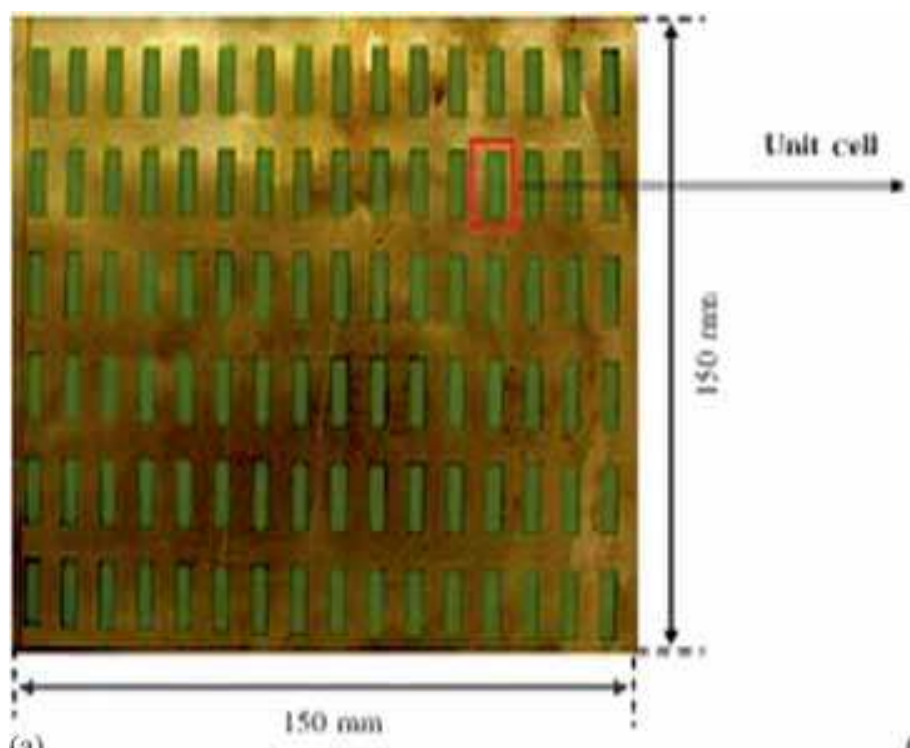

(a)

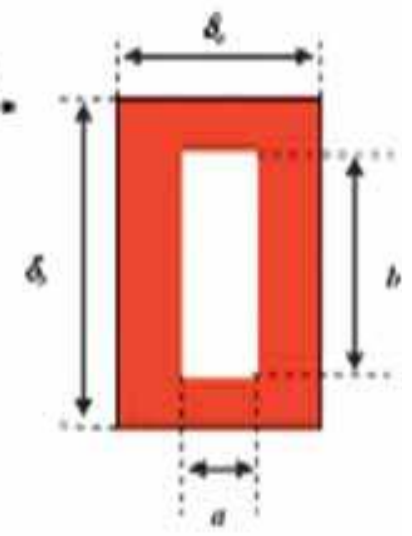

(b)

Figure 2. Frequency selective surface: (a) photograph and (b) the unit cell.

Table 2. Dielectric constant and loss tangent of the materials.

\begin{tabular}{lcc}
\hline Material & $\begin{array}{c}\text { Dielectric } \\
\text { constant }\end{array}$ & $\begin{array}{c}\text { Loss } \\
\text { tangent }\end{array}$ \\
\hline Glass fibre/epoxy composite [12] & 4.975 & 0.031 \\
Nylon 6/6 [13] & 3.4 & 0.04 \\
PVC foam [10] & 1.702 & 0.014 \\
Balsa wood [14,15] & 1.22 & 0.047 \\
Epoxy resin [18] & 3.8 & 0.03 \\
\hline
\end{tabular}

The frequency at which maximum transmission occurs is the resonance frequency.

Choi et al [17] argue that 'the transmission loss $L_{\text {tr }}$ is calculated using the logarithmic scale ratio of $E_{\mathrm{t}}$ (transmissted EM wave electric field intensity) to $E_{\mathrm{i}}$ (incident EM wave electric field intensity) expressed by as follows':

$$
L_{\mathrm{tr}}=10 \log \left|\frac{E_{\mathrm{t}}}{E_{\mathrm{i}}}\right|^{2}(\mathrm{~dB}) .
$$

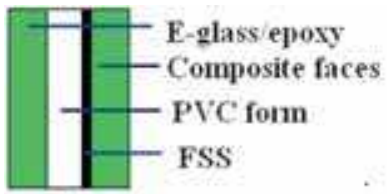

(a)

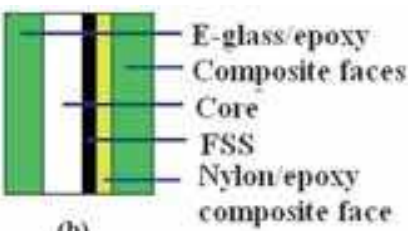

(b)

composite face

Figure 3. Schematic diagram of sandwich constructions: (a) reference sandwich and (b) modified sandwich.

$$
\left|\frac{E_{\mathrm{t}}}{E_{\mathrm{i}}}\right|^{2}=\frac{10 L_{\mathrm{tr}}}{10} \times 100(\%) .
$$

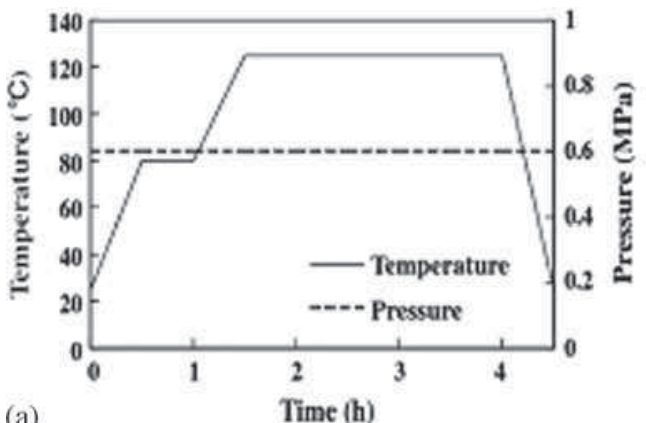

(a)

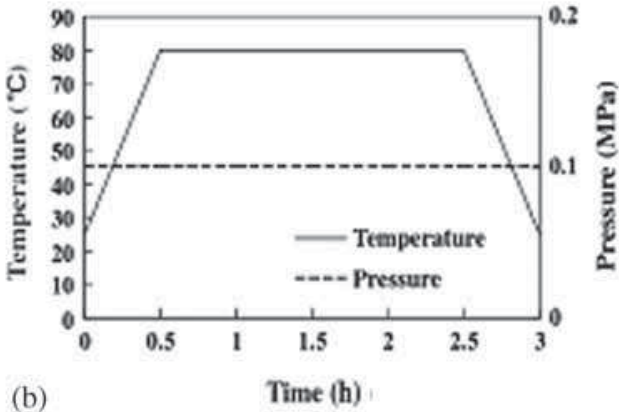

(b)

Choi et al [17] argue that 'the transmission rate is calculated by as shown below'$$
\frac{2}{2}
$$

Figure 4. Bonding and curve cycles for the sandwich RAS: (a) fabricating the E-glass/epoxy and nylon/epoxy composites and (b) bonding of the composites faces, core and FSS. 
Table 3. Sandwich type, configuration and identification code.

\begin{tabular}{|c|c|c|}
\hline Sandwich type & Configuration & Identification code \\
\hline \multirow[t]{3}{*}{ Type 1} & $\begin{array}{c}8 \text { Layers of E-glass/epoxy prepreg }+ \text { PVC }+2 \\
\text { layers of nylon/epoxy prepreg }+6 \text { layers of } \\
\text { E-glass/epoxy prepreg }\end{array}$ & 1.a \\
\hline & $\begin{array}{c}8 \text { Layers of E-glass/epoxy prepreg }+\mathrm{PVC}+4 \\
\text { layers of nylon/epoxy prepreg }+4 \text { layers of } \\
\text { E-glass/epoxy prepreg }\end{array}$ & 1.b \\
\hline & $\begin{array}{c}8 \text { Layers of E-glass/epoxy prepreg }+ \text { PVC }+6 \\
\text { layers of nylon/epoxy prepreg }+2 \text { layers of } \\
\text { E-glass/epoxy prepreg }\end{array}$ & 1.c \\
\hline \multirow[t]{3}{*}{ Type 2} & $\begin{array}{c}8 \text { Layers of E-glass/epoxy prepreg }+ \text { balsa wood } \\
+2 \text { layers of nylon/epoxy prepreg }+6 \text { layers of } \\
\text { E-glass/epoxy prepreg }\end{array}$ & 2.a \\
\hline & $\begin{array}{c}8 \text { Layers of E-glass/epoxy prepreg }+ \text { balsa wood } \\
+4 \text { layers of nylon/epoxy prepreg }+4 \text { layers of } \\
\text { E-glass/epoxy prepreg }\end{array}$ & 2.b \\
\hline & $\begin{array}{l}8 \text { Layers of E-glass/epoxy prepreg }+ \text { balsa wood } \\
+6 \text { layers of nylon/epoxy prepreg }+2 \text { layers of } \\
\text { E-glass/epoxy prepreg }\end{array}$ & 2.c \\
\hline
\end{tabular}

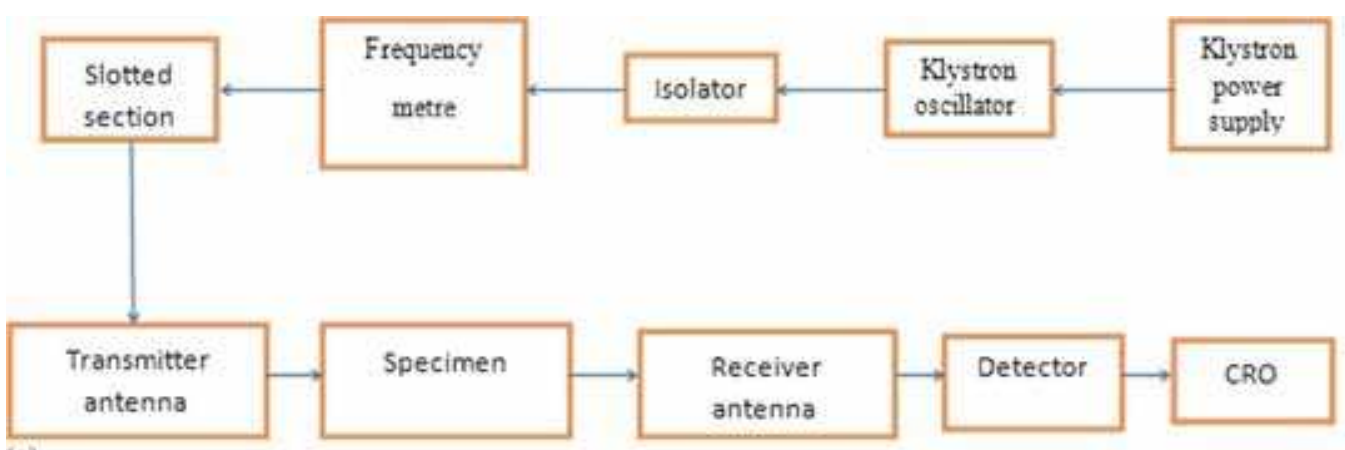

(a)

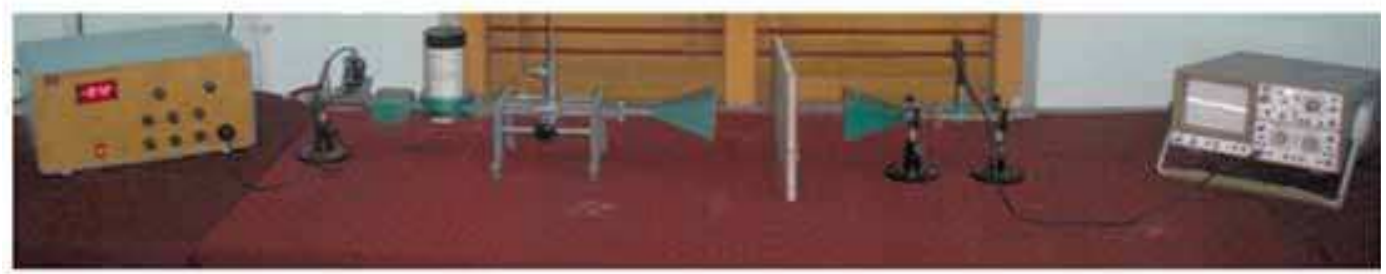

(b)

Figure 5. Free space measurement system: (a) block diagram and (b) photograph.

The frequency range over which $80 \%$ transmission rate observed is in the bandwidth for $-1 \mathrm{~dB}$.

\section{Flexural strength investigation}

Choi et al [11] argue that "three point bending test is performed to measure the flexural strength of the sandwich RAS construction according to ASTM D790-03 with five specimens for each type of sandwich configuration shown in figure 6'. The width $(W)$, span $(L)$ and diameter $(d)$ of the supporting fixtures are 30,176 and $8.5 \mathrm{~mm}$, respectively.
Choi et al [18] argue that 'the flexural strength of the sandwich construction is calculated by'.

$$
\sigma_{\mathrm{cr}}=\frac{3 P L}{2 W t^{2}} .
$$

\section{Experimental work and discussion}

The EM wave transmission characteristics are shown in table 4.

There is a positive shift in resonance frequency as the number of nylon/epoxy prepreg is increased. The maximum 

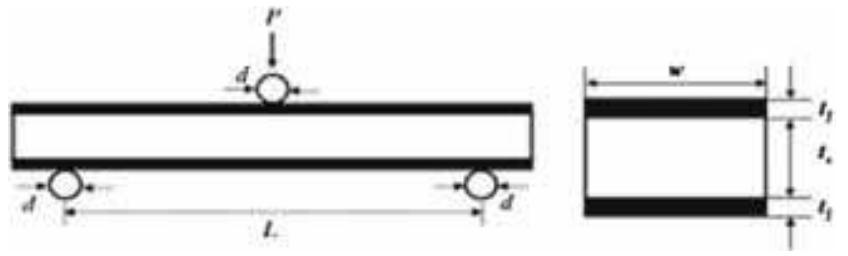

Figure 6. Loading configuration and cross-section.

Table 4. EM wave transmission characteristics.

\begin{tabular}{lccc}
\hline $\begin{array}{l}\text { Specimen } \\
\text { identification } \\
\text { code }\end{array}$ & $\begin{array}{c}\text { Resonance } \\
\text { frequency } \\
(\mathrm{GHz})\end{array}$ & $\begin{array}{c}\text { Maximum } \\
\text { transmission } \\
\text { rate }(\%)\end{array}$ & $\begin{array}{c}\text { Bandwidth } \\
\text { for }-1 \mathrm{~dB} \\
(\mathrm{GHz})\end{array}$ \\
\hline $1 . \mathrm{a}$ & 8.61 & 83 & 0.59 \\
$1 . \mathrm{b}$ & 9.11 & 86 & 0.63 \\
$1 . \mathrm{c}$ & 9.63 & 89 & 0.69 \\
$2 . \mathrm{a}$ & 8.73 & 84 & 0.61 \\
$2 . \mathrm{b}$ & 9.22 & 88 & 0.69 \\
$2 . \mathrm{c}$ & 9.84 & 92 & 0.74 \\
\hline
\end{tabular}

transmission rate and bandwidth of $-1 \mathrm{~dB}$ is also increased. This is due to the fact the dielectric constant of nylon/epoxy composite are lesser than the glass/epoxy composite. Further improvement in EM wave transmission characteristics are observed in type 2, sandwich configuration as balsa wood is low dielectric than PVC foam.

The EM wave transmission characteristics is shown in figure 7 .

The load-displacement curve for the sandwich configuration is shown in figure 8 .

There is a drop in the failure load from type 1.a to 1.c and 2.a to 2.c. This was due to the reason that the glass fibre was stronger than nylon 6/6 fibres. The type 2 sandwich configurations is stronger than type 1 . The presence of balsa wood as the core increased the load bearing capability of the specimens. Further increase in nylon 6/6 layers would decrease the flexural strength considerably, which could not be compensated by the balsa wood. The flexural strength for each type of the sandwich configuration is shown in figure 9 .

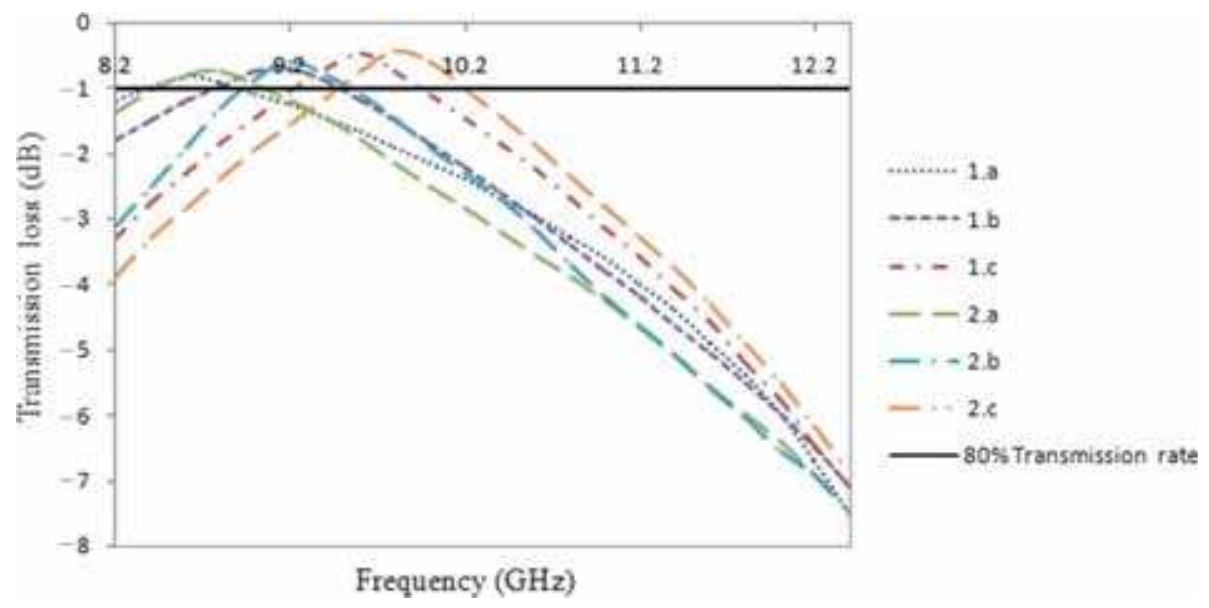

Figure 7. EM wave transmission characteristics.

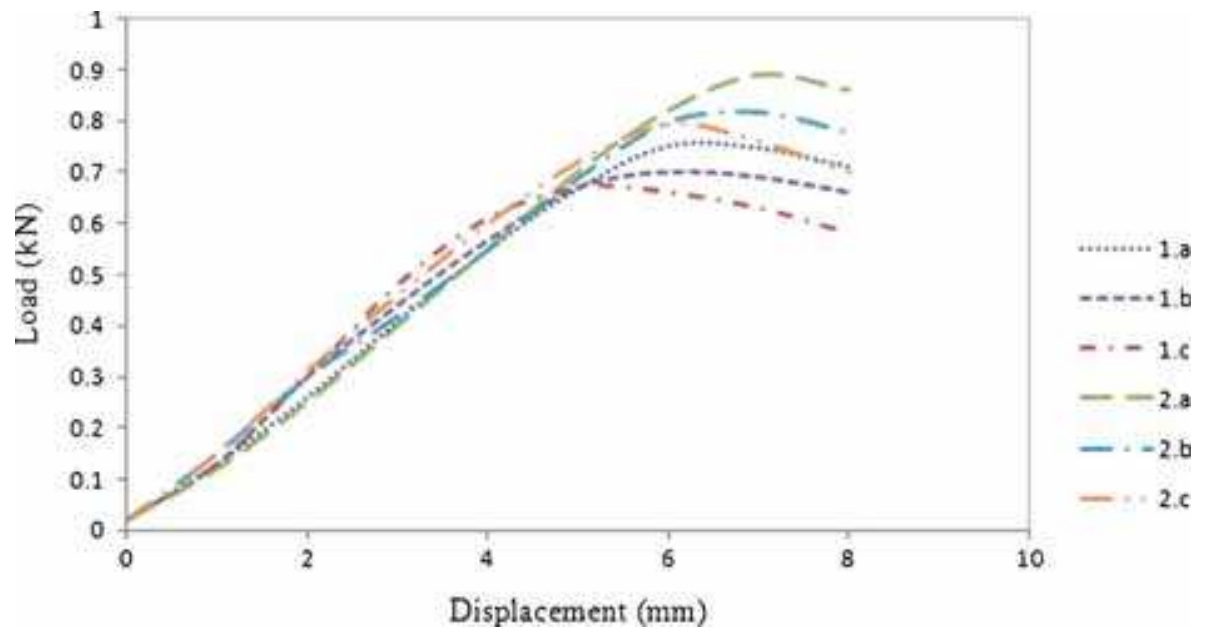

Figure 8. Load-displacement curves. 


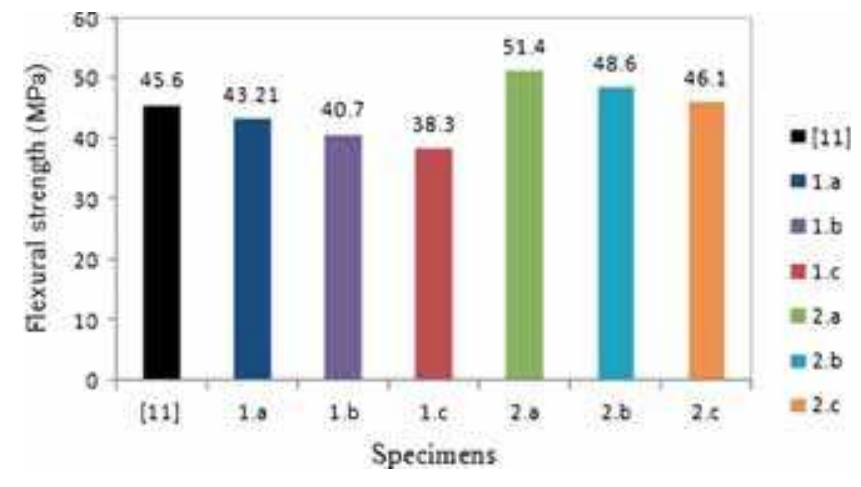

Figure 9. Flexural strength of the RAS.

\section{Conclusion}

The ideally invisible stealth radomes are usually sandwich constructions composed of E-glass/epoxy composite, PVC foam and FSS. Nylon fibre and balsa wood are well known for their low dielectric properties. Thus the wave transmission characteristics of the stealth radomes are improved by employing nylon fibre and balsa wood along with glass/epoxy composite without compromising the mechanical properties. The type 2.c sandwich construction is suggested as equivalent replacement for the existing radome with improved EM wave transmission characteristics. The free space measurement technisque is performed to measure the wave transmission characteristics in the X-band frequency range $(8.2-12.4 \mathrm{GHz})$ for the specific FSS. The flexural strength of the sandwich constructions are investigated with three-point bending test.

\section{Acknowledgements}

This project was purely inspired by the works of Lee DG et al. The authors honor their research. The technical support is provided by Jaya KJ, Shanti N, Amala SS, Arockia SSG and Sucharitha M-Faculty of Electronics and Communication Engineering, Noorul Islam University, Kumaracoil, India. The authors thank them. The EM transmission characteristics were measured in Microwave Laboratory, Noorul Islam University, Kumaracoil, India. The three-point bending test is performed in Omega Inspection \& Analytical Laboratory—Chennai, India.

\section{References}

[1] Rao G A and Mahulikar S P 2002 Aeronaut. J. 106629

[2] Mahulikar S P, Sonawane H R and Rao G A 2007 Prog. Aerospace Sci. 43218

[3] Chin W S and Lee D G 2006 Science Direct-Elsevier Compos. Struct. $\mathbf{7 4} 153$

[4] Kim P C and Lee D G 2009 Science Direct_Elsevier Compos. Struct. 87161

[5] Kim P C, Chin W S, Lee D G and Seo I S 2006 Science Direct-Elsevier Compos. Struct. 75601

[6] Seo I S, Chin W S and Lee D G 2004 Science Direct-Elsevier Compos. Struct. 66533

[7] Chin W S and Lee D G 2007 Science Direct-Elsevier Compos. Struct. 77457

[8] Kim P C, Lee D G, Seo I S and Kim G H 2008 Science Direct-Elsevier Compos. Struct. 86299

[9] Choi I, Kim J G, Lee D G and Seo I S 2011 Science DirectElsevier Compos. Struct. 932740

[10] Kim P C, Lee D G, Seo I S and Kim G H 2008 Science Direct-Elsevier Compos. Sci. Technol. 682163

[11] Choi I, Kim J G, Lee D G and Seo I S 2011 Science DirectElsevier Compos. Sci. Technol. 711632

[12] Chin W S and Lee D G 2007 Science Direct-Elsevier Compos. Struct. 77373

[13] Naidu M S and Kamaraju V ed 2013 High voltage engineering (Noida: Tata McGraw Hill Education)

[14] Middleton W and Valkenburg M E V 2001 Reference data for engineers (Amsterdam: Newnes) 9th ed

[15] USA Department of Commerce 1972 Dielectric constant and loss data (Ohio: National Technical Information Service) (AFML-TR-72-39)

[16] Kim P C, Lee D G, Lim W G and Seo I S 2009 Science Direct-Elsevier Compos. Struct. 90242

[17] Choi I, Kim J G, Seo I S and Lee D G 2012 Science DirectElsevier Compos. Struct. 943394

[18] Choi I, Kim J G, Seo I S and Lee D G 2012 Science DirectElsevier Compos. Struct. 943002 